\title{
A review on the novel discoveries of Begomoviruses in Oman
}

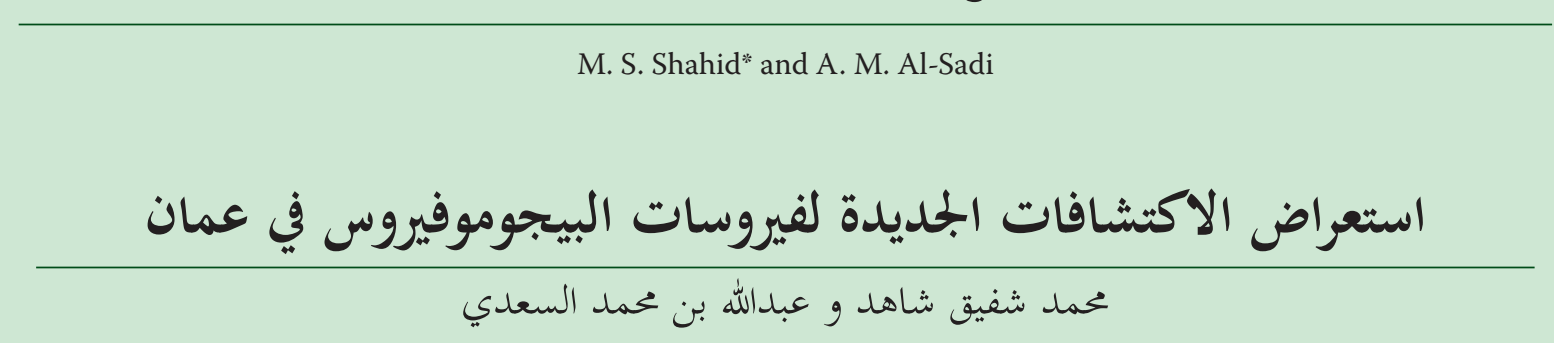

Abstract. Begomoviruses (family; Geminiviradae) consist of single-stranded (ss) and circular genome particles. They are transmitted by whiteflies, and represent a major constraint to agricultural crops in different parts of the world. In Oman, they have been causing huge losses to crops (tomato, cucumber, watermelon and beans). Research on begomoviruses in Oman over the last years focused on molecular characterization, phylogenetic relationship, recombination analysis, pathogenicity test on model and host plants and the development of transgenic plants with resistance. Some studies focused on the association of DNA satellites (alphasatellite and betasatellite) molecules with begomoviruses. This review highlights the latest developments in begomovirus and associated DNA satellites discoveries in Oman over the last three decades. This period encountered changes in agricultural practices and developments in virus detection technologies from morphological to the application of genome diagnostics to the emergence of high throughput DNA sequencing, capable to sequence multiple and diverse DNA molecules in parallel, enabling of millions of DNA molecules to be sequenced at a time. In addition, several tomato cultivars bearing different Ty genes having resistance to TYLCD complex were developed.

KEYwORDS: viruses, whitefly, transmission

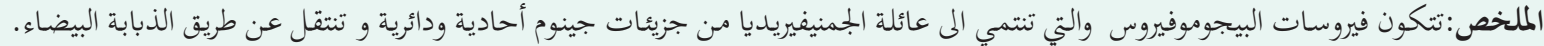

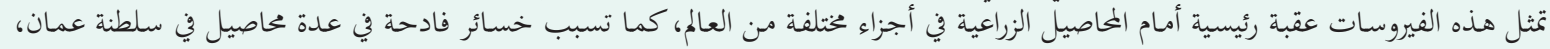

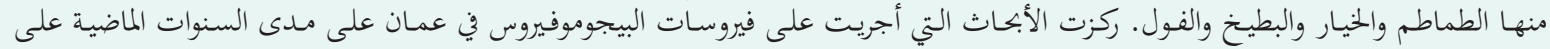

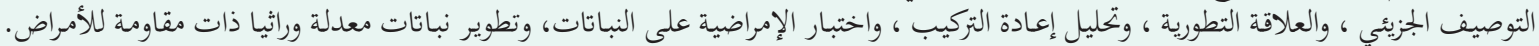

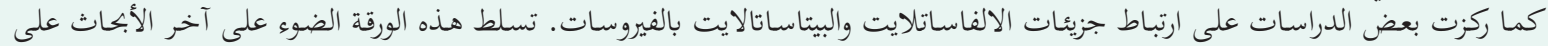

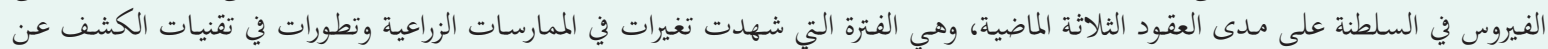

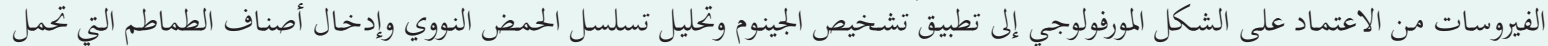

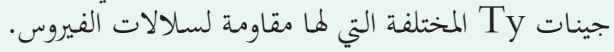

$$
\begin{aligned}
& \text { الكلمات المفتاحية: الفيروسات، الذبابة البيضاء، الانتقال. }
\end{aligned}
$$

\section{Introduction}

G eminiviridae is a family of plant pathogens characterized by geminate (twin) icosahedral particles containing a circular single stranded DNA (ssDNA) genome. Based on variability in their genome organization, insect vectors and host range, they are divided into nine different genera: Mastrevirus, Curtovirus, Topocuvirus, Begomovirus, Capulavirus, Eragrovirus, Becurtovirus, Turncurtovirus and Grablovirus (Zerbini et al., 2017). Among all genera, Begomovirus is the largest genus in the Geminiviridae, having more than 200 species vectored by whiteflies (Bemisia tabaci, Gennadius) (Zerbini et al., 2017). Begomoviruses are known to cause severe damage to many dicot plants in tem-

M. S. Shahid ( ences, College of Agricultural and Marine Sciences, Sultan Qaboos University, Al-Khod 123, Oman, ORCID: M. S. Shahid : https://orcid. org/0000-0002-3550-0000 perate, subtropical, and tropical agroecosystems. The genome of begomoviruses is either bipartite, consisting of two (DNA A and DNA B) genomic components, approximately $2.6-2.8 \mathrm{~kb}$ in size or monopartite (DNA A) consisting of a single component ranging from 2.6 to $2.8 \mathrm{~kb}$ in size. The bipartite begomoviruses frequently occur in the New World (NW), which includes Central America and South America, while the monopartite begomoviruses are commonly found in the Old World (OW), which consists of Australia, Japan, China, Indian subcontinent, Africa, Mediterranean and European region (Zerbini et al., 2017). The DNA A component of begomoviruses originating from the OW consists of genes that encode six proteins (Rep, TrAp, REn, CP and $\mathrm{V} 2$ and $\mathrm{C} 4$ ).

In the OW, the majority of monopartite begomoviruses are associated with betasatellites (family Tolecusatellitidae, genus Betasatellite) (Briddon et al., 2018; Zhou et al., 2013), which are circular ssDNA molecules 
of 1350 nucleotides (nt) in size. Betasatellites depend on a helper virus (the main virus DNA genome) for replication, movement, and transmission between plants (Briddon et al., 2002, 2001; Saunders et al., 1999; 2004; 2008). However, they have no sequence similarity to their helper begomoviruses, except the hairpin structure, which has resemblance to the region of geminiviruses replication which contains the nonanucleotide (TAATATTAC) sequence (Briddon et al., 2003). Many begomovirus strains and associated satellites have been identified in Oman on various plants, including vegetable, legume, medicinal, weed and fruits crops. Contemplating the significance of begomoviruses to Omani agriculture, the significant research accomplishments on begomoviruses in Oman over the last three decades are presented in this review.

\section{Agriculture in Oman}

Being a non-agricultural country as well as its geographical location, Oman has historical trade relations with various countries around the globe, particularly with Asian and African countries. Agricultural commodities in Oman are particularly imported from Iran, India, Pakistan, Egypt, Lebanon and from various other countries. The agricultural produce of Oman, mainly in winter season, is grown primarily for local consumption except for certain export to some neighbouring countries like UAE. Al Batinah North and Dhofar in the south are the main agricultural cultivation areas in Oman. According to MAF (2015) (www.maf.gov.om), the total area under cultivation in Oman is 67,000 ha, though most of planting material is imported from different countries. The import of planting material for commercial farms or via travellers and workers has led to the introduction of different begomoviruses into Oman. The exchange of planting material among farmers as well as local propagation of imported planting material that is infected with viruses helped spread viruses locally.

\section{Begomovirus Research in Oman}

Over the past few years, extensive work has been carried out on the detection and characterization of begomoviruses in Oman (originated from different countries) (Figure 1). Studies on begomoviruses utilized polymerase chain reaction (PCR), rolling circle amplification (RCA), cloning, restriction endonuclease analysis, and the application of next generation sequencing technology (NGS). Extensive research has been done on begomoviruses on their sequence analysis, phylogeny, pathogenicity, plant-virus interactions, pathogen-derived transgenic resistance as well as characterization of DNA satellites. Until now different begomoviruses and DNA satellites have been discovered from 16 different agricultural crops in Oman (Table 1). This review outlines the main crops affected by begomoviruses in Oman.

\section{Tomato (Lycopersicon esculentum)}

Tomato is a leading vegetable crop, which is cultivated mainly in the Al-Batinah. Begomoviruses are the major biotic factor limiting tomato production in Oman (Fig. 4c). Tomato leaf curl disease (ToLCD) plants showing variable symptoms (yellow, upward curling, stunting and bushy appearance) were observed by the MAF in the early 1990s. However, the causal organism of the disease was characterized late in 2004. Tomato plants displaying symptoms of ToLCD were collected from tomato fields during the winter season of 2004-2005. Nucleic acid was extracted and used in rolling circle amplification (RCA). Sequence analysis showed 91\% nt identity with the Iranian strain of tomato yellow leaf curl virus (TYLCV). Similarly, sequence analysis of associated betasatellite showed $88.5 \%$ nt identity with tomato leaf curl betasatellite (ToLCB) reported from Pakistan. This study was the first to report TYLCV and ToLCB causing ToLCD in Oman (Khan et al., 2008). In 2011, a complex of TYL$\mathrm{CV}$ and a recombinant species of Tomato leaf curl Oman virus (ToLCOMV) associated with an alphasatellite and ToLCB were discovered. The alphasatellite shared maximum nt identity with ageratum yellow vein Singapore alphasatellite (AYVSGA), which is unusual DNA-2-type alphasatellite that is rarely associated with monopartite begomovirus complex. The pathogenicity study was also done using Agrobacterium-mediated inoculation and it was found that in the coinfection with begomovirus complex, AYVSGA ameliorate the symptoms developed by the TYLCV and ToLCB (Idris et al., 2011; Shahid et al., 2020a). Afterward, a recombinant begomovirus of an African origin, Tomato leaf curl Sudan virus (ToLCSDV), was identified near the Yemen border. Surprisingly, no betasatellite was detected from the tomato plants harbouring ToLCSDV. Infectivity was achieved through infectious constructs in N. benthamiana and tomato plants. However, effort to find the interaction of ToLCSDV with ToLCB in model host plant was not successful (Khan et al., 2012a).

Later, different begomovirus strains such as Chilli leaf curl virus (ChiLCV), Tomato leaf curl Al-Batinah virus (ToLCABV) and Tomato leaf curl Barka virus (ToL$\mathrm{CBV}$ ) were also reported to infect tomato in Oman. To avoid further tomato production losses, resistant tomato lines (provided by the World Vegetable Centre, Taiwan) were screened under natural conditions in two different locations. During data recording, ToLCD symptoms were observed on few lines, and the infected leaves were collected and processed for virus identification. Surprisingly, a recombinant begomovirus, showing the maximum levels of identity (92.9-93\%) to the newly reported Cotton leaf curl Gezira virus (CLCuGeV) in the UAE was detected (KJ939446; Idris et al., 2014). Based on the 91\% criteria for begomovirus strain identification by the ICTV (Brown et al., 2015), the name "Al Batinah" for $\mathrm{CLCuGeV}$ was proposed. The identified CLCuGeV-AB 


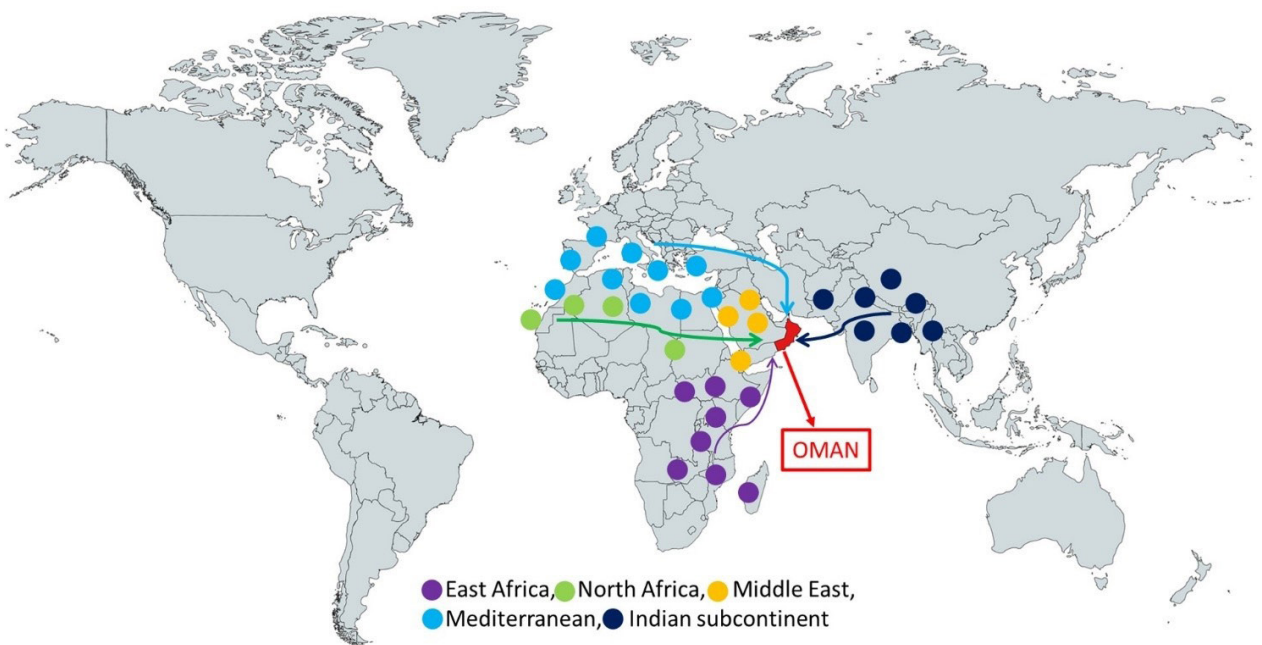

Figure 1. The world depicting possible origin and migration routes of begomoviruses identified in Oman, mainly from East and North Africa (purple and green arrows), Middle east (Brown arrow), Mediterranean (blue arrow) and Indian subcontinent (dark blue arrow).

begomovirus is a recombinant strain which evolved through intraspecific and interspecific recombination from the "Sudan" strain of CLCuGeV (KJ939446) and Oman strain of CLCuGeV (HF536716) (Figure 3a). The interspecific recombination events showed the presence of a DNA fragment from an African cassava mosaic virus (ACMV), discovered from Burkina Faso (Figure 3b). Recently, ToLCD caused by mixed infection was identified using NGS technology, where mixed infection was identified from tomato plants infected with TYLCV-IR strain, ToLCB and a legume infecting bipartite begomovirus, Mungbean yellow mosaic India virus (MYMIV). The biological activities of the whole virus complex were also studied in N. benthamiana (a model host) and tomato (natural) host plants (Shahid et al., 2019b).

\section{Cassava (Manihot esculenta)}

Oman has long relations with Zanzibar in Africa, where many Omanis brought cassava tubers back into Oman. Although, the cultivation of cassava is at a limited scale in Oman, cassava mosaic disease (CMD) was observed during a begomovirus survey in A'Seeb, Muscat. A single bipartite begomovirus, East African cassava mosaic Zanzibar virus (EACMZV), has been identified as the causative agent for CMD in Oman (Khan et al., 2013a) (Figure 3b). This virus has narrow geographical distribution as it was only reported from Zanzibar and Kenya. This suggests that EACMZV has been imported through cassava tubers into Oman. The Bemisia tabaci population was also noticed on infected cassava plants in Oman, yet their contribution in CMD dissemination has not been studied. Since cassava is grown at a small scale in Oman, which is very isolated from the major cassava cultivation regions of the world, so it should be easy to wipe out CMD in the country by the establishment of virus-free cassava tubers, subject to proper quarantine measures to avoid future incursions. However, the emergence of CMD in Oman emphasizes how the human activities can disseminate plant pathogens, as reported for other crops (Phytophthora. Ramorum in Northern California) (Cushman et al., 2008).

\section{Cucurbits}

Watermelon chlorotic stunt virus (WmCSV), a Middle Eastern virus, and Squash leaf curl virus (SLCV), having a New World origin, are two bipartite begomoviruses that cause severe economic losses to Cucurbitaceae plants throughout the Middle East and the world. The first molecular characterization of WmCSV was from Squash (Cucurbita moschata) plants in Oman. The $C$. moschata plants exhibiting begomovirus symptoms were observed (Figure 4g) in an experimental field in the Agriculture Experimental Station (AES), Sultan Qaboos University Oman. Sequence analysis revealed the highest nt identity with DNAA and DNA B components of WmCSV isolates of Iran (Khan et al., 2012b; Shafiq et al., 2020). Pathogenicity of the virus was confirmed using agrobacterium mediated inoculation into $N$. benthamiana model host plants. $N$. benthamiana plants did not show any visible symptoms following inoculation with DNA A only. However, $N$. benthamiana plants produced obvious symptoms after 15 days of inoculation when inoculated with DNA A and DNA B (Khan et al., 2012b). Watermelon (Citrullus lanatus) is an essential summer food crop in Oman. In 2015, C. lanatus plants displaying yellow, leaf curling, and crumpling symptoms with a disease incidence of $70 \%-80 \%$ were observed at SQU, Oman. The genomic components verified to be the monopartite begomovirus ChiLCV and ToLCB infecting watermelon plants (Shahid et al., 2017b; 2020b).

Cucumber (Cucumis sativus) is another greenhouse crop extensively grown in Oman. Recently, C. sativus 
plants showing yellow mosaic and crumpling, symptoms typical of begomovirus infection were observed (Figure 4b). Also, medium to high density of whitefly population was observed on cucumber plants in Barka farms. The whitefly is a complex of more than 40 crypitc species, or biotypes, including the widespread Middle East-Asia Minor 1 (MEAM1 or B biotype) and Mediterranean (MED or Q biotype). Transmission of begomoviruses solely depends on their interaction with $B$. tabaci, where begomoviruses have to cross the certain barriers situated in the whitefly where some of the proteins bind with the Coat Protein (Czosnek et al., 2017; Fiallo-Olivé et al., 2019). After cloning and sequencing analysis, it was confirmed the MYMIV is associated with the cucumber disease (Shahid et al., 2018).

Squash leaf curl virus (SLCV) is a NW begomovirus, but according to few reports, it has been identified from many Middle Eastern countries like Jordan, Israel and Egypt. Recently, squash plants showing severe symptoms typical of begomovirus infection were observed on squash plants (Fig. 4e). In molecular analysis, viral genome DNA A and DNA B components were produced and sequenced. Sequence analysis confirmed that the squash plants are infected with a bipartite begomovirus SLCV, which has highest similarity with an SLCV isolate reported from Israel (IsSq-C2; KT099165, Rosario et al., 2015) (Figure 3b). SLCV is the first NW begomovirus infecting squash in Oman (Shahid et al., 2020c) (Table 1). Since, different exotic monopartite begomoviral strains have been discovered to infect agricultural crops in Oman and the introduction of another bipartite begomovirus may cause extra risk through interaction with the former begomoviral strains.

\section{Legumes}

Yellow mosaic disease (YMD) is a vast spread disease of legumes in South Asia. YMD was first identified during 1960 in India (Nariani, 1960), infecting blackgram (Vigna mungo) and mungbean ( $V$. radiata) and resulted in huge losses to legume production. Among legumes, Kidney bean (Phaseolus vulgaris) is a commonly grown vegetable crop in Oman. During a field visit in 2015, foliar mosaic, yellow, and crumpling symptoms, with whitefly population, was observed on kidney bean plants. Genomic DNA isolation followed by begomovirus identification using PCR and RCA was done. Sequencing and sequence analysis confirmed mixed infection by Mungbean yellow mosaic India virus (MYMIV), which was associated with ToLCB. Sequence analysis of DNA A sequences indicated $99 \%$ nt sequence identity (Figure 2B), which confirms that a single begomovirus species is involved in the disease. In recombination analysis, DNA A sequence showed potential intraspecific genome recombination with MYMIV-PK and MYMIV-IN strains as the major and minor parents, respectively. The sequence of the homolog DNA B of MYNIV showed $97.8 \%$ nt sequence identity with
MYMIV-IN isolate, which was further verified by phylogenetic analysis (Table 1). The MYMIV Oman demonstrated the greatest levels of nt identity to the isolates reported in Southeast Asia (Shahid et al., 2017). MYMIV are member of "legumoviruses" which are very unique among other bipartite begomoviruses discovered in the OW and phylogenetically they have a diverse group of begomoviruses (Ilyas et al., 2009) (Fig. 2B). MYMIV is common in India, Pakistan, Nepal, Indonesia and China (Tsai et al., 2013). Oman is far away in west, where the MYMIV has been reported. The isolates of the virus reported in Oman have high identity to isolates identified from India from cowpea plants. This possibility leads to indicate that this unusual MYMIV has been possibly imported from the South Asian county (India).

\section{Okra (Abelmoschus esculentus)}

Okra (Abelmoschus esculentus) is an extensively cultivated vegetable crop, and it is believed to be originated from western Africa. It is widely cultivated during winter season from small to large scale in different regions of Oman. Okra leaf curl disease (OLCD) is a main problem in okra cultivation. OLCD is characterized by curling, distortion, yellowing, mottling, mosaic, and stunted growth (Figure 4h). In Oman OLCD is caused by a begomovirus and associated betasatellites and alphasatellites (Akhtar et al., 2014). The analysis of sequences confirms that the begomovirus has maximum identity (85\%) with CLCuGeV (Figure 2A). Since the nt sequence identity of virus was lower according to the criteria set for species demarcation by International Committee on Taxonomy of Viruses (ICTV), hence it was discovered as a new virus species which was named as Okra leaf curl Oman virus (OLCOMV). Further sequence analysis showed that the OLCOMV has evolved through different recombinant events among $\mathrm{CLCuGeV}$ and TYLCV-OM. The sequence analysis of DNA satellite revealed that betasatellite seemed to be of African origin, known as okra leaf curl betasatellite (OKLCB) and the okra leaf curl alphasatellite (OKLCA) of Middle East origin. Although several begomovirus and DNA satellites complexes have been identified from Okra plants globally, however in Oman a single monopartite begomovirus complex has been reported. This monopartite begomovirus complex infecting okra possibly provides an environment for mixed infection, which leads to the evolution of recombinant viruses and satellites through mutation and genomic components exchange.

\section{Papaya (Carica papaya)}

Papaya (Carica papaya) belonging to the Caricaceae family and it is a dicot woody plant, native to Mexico, America (Central and South) but now adapted to almost all tropical regions (https://www.arabnews.com/ node/344838). Due to its dietary benefits and demand, its production has been significantly increased over the last few decades in different countries. Papaya is a wide- 

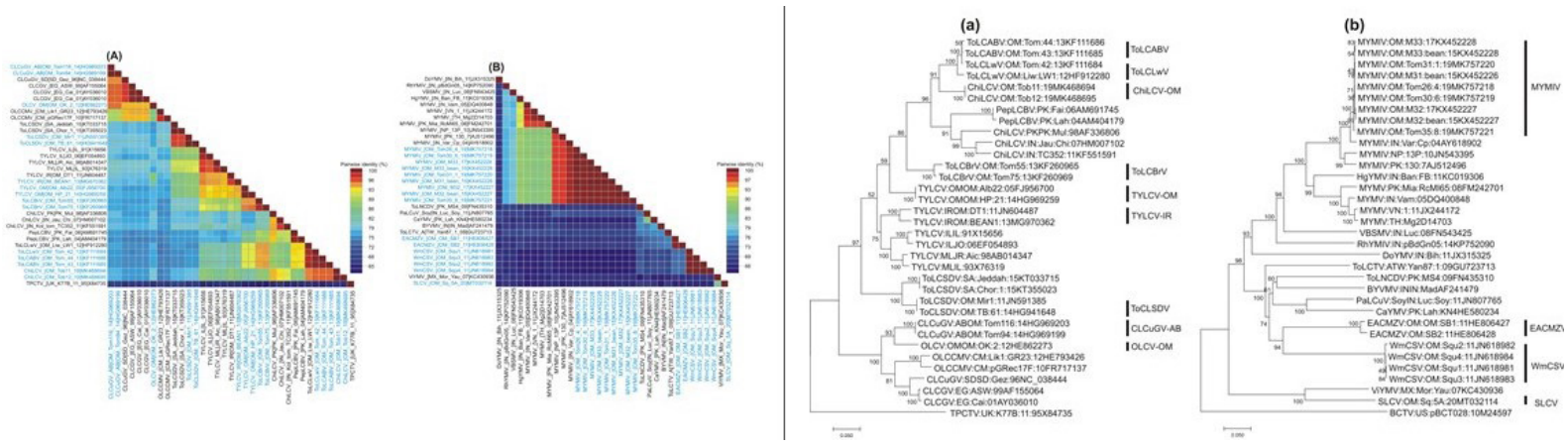

Figure 2. Species Demarcation Tool analysis of monopartite begomoviruses (A) and bipartite begomoviruses (B).

ly grown fruit in Salalah, and as a minor crop in other regions of Oman, with an approximately 20 tons of fruit production annually. Symptomatic papaya plants were collected from Quriyat (Figure 4f). The viral DNA was PCR amplified, cloned and sequenced. Genome analysis revealed that the amplified virus components showed 83.3\%-95.1\% nt identity to $\mathrm{CLCuGeV}$ genome (Figure 2A). Further analysis confirmed that the $\mathrm{CLCuGeV}$ has recombination with TYLCV-Iran strain as a major parent (Khan et al., 2012a). Different begomovirus species have been reported to infect papaya plant from SouthEast Asian countries, but so far, a single begomovirus infecting this crop has been identified in Oman. However, there are ongoing studies on the geographical distribution and genetic diversity of plant viral strains infecting papaya crop in the country.

\section{Chillies (Capsicum annuum L.)}

Chillies are an extensively grown vegetable crop after tomato in open fields during winter in Oman. Chili leaf curl disease (CLCD) causes main losses to the chili crop across the Old World and is caused by several begomoviruses (monopartite and bipartite). CLCD was first documented in India during the 1960s (Dhanraj and Seth, 1968). Later this disease spread into the neighbouring countries. In Oman, leaf curl disease of chilli was investigated using RCA and agrobacterium mediated inoculation approaches. In extensive surveys during 2010-2011, virus and betasatellite genomes were produced and sequenced completely. According to the sequence analysis with the accessions in the GenBank, they showed the maximum nt identity between $88.0 \%$ and $91.1 \%$ to the isolates of "Pakistan" strain of ChiLCV, indicating a different strain of ChiLCV for which the name as ChiLCV-Oman strain (ChiLCV-OM) was proposed. On the other hand, the betasatellite genome sequences exhibited the highest nt identity to a an earlier identified ToLCB (Khan et al., 2013b; 2013c). Infectious clones were produced, and infectivity analysis confirmed the biological role of ChiLCV and ToLCB in disease development in $N$. benthamiana and tomato plants. However, efforts to infect chilli plants with ChiLCV-OM or with ToLCB were not successful through agrobacterium mediated inoculum, nevertheless under natural field conditions virus and satellite can transmit the disease through the vector (B. tabaci).

\section{Radish (Raphanus sativus)}

Radish, family Brassicaceae, is an essential and widely grown winter vegetable crop in Oman. It is usually grown as a mix crop along with cabbage, carrot, lettuce and squash. In an earlier study, reddish plants exhibiting typical symptoms of begomovirus infection were observed in Al-Batinah, with severity ranging from $50-80 \%$. The infected leaves were collected to investigate the pathogen. Molecular analysis proved that the disease is due to mixed infections of TYLCV and ChiLCV (Al-Shihi et al., 2018a). The begomovirus strains identified from radish showed $99 \%$ identity to the isolates of TYLCV and ChiLCV (Table 1).

The agrobacterium mediated inoculation assays suggested mixed infection as evident from different viral symptoms compared with the single virus infection in $N$. benthamiana plants, which were further confirmed by southern hybridization and real time PCR analysis (Al-Shihi et al., 2018b). After individual inoculation of TYLCV or ChiLCV to N. benthamiana plants, typical begomovirus infections were produced. However, in co-inoculation with TYLCV and ChiLCV, the symptom severity has been enhanced. Southern hybridization and Real-time $\mathrm{qPCR}$ confirmed that both viruses interact synergistically where virus load and copy number increased in co-inoculation experiments compared with single virus inoculation (Al-Shihi et al., 2017). 


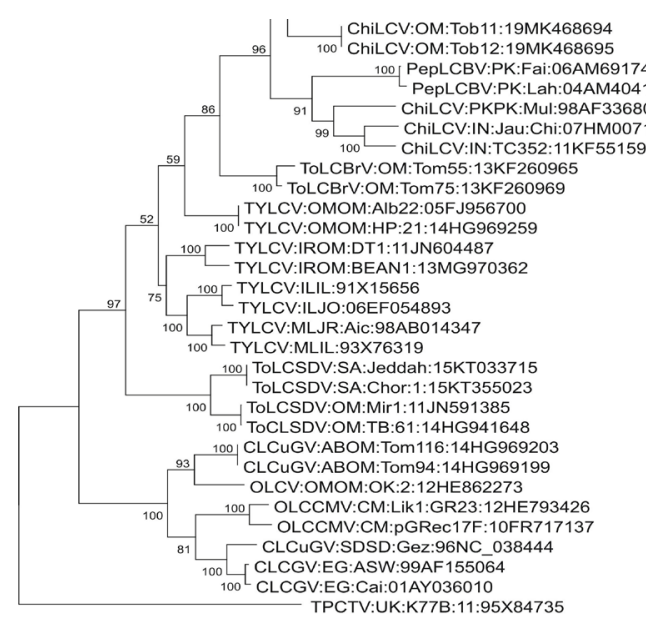

$\stackrel{.050}{\longmapsto}$

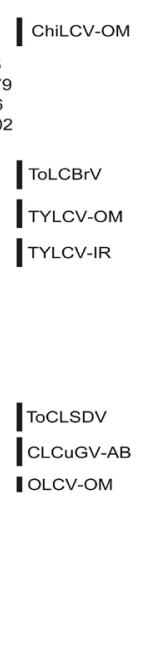

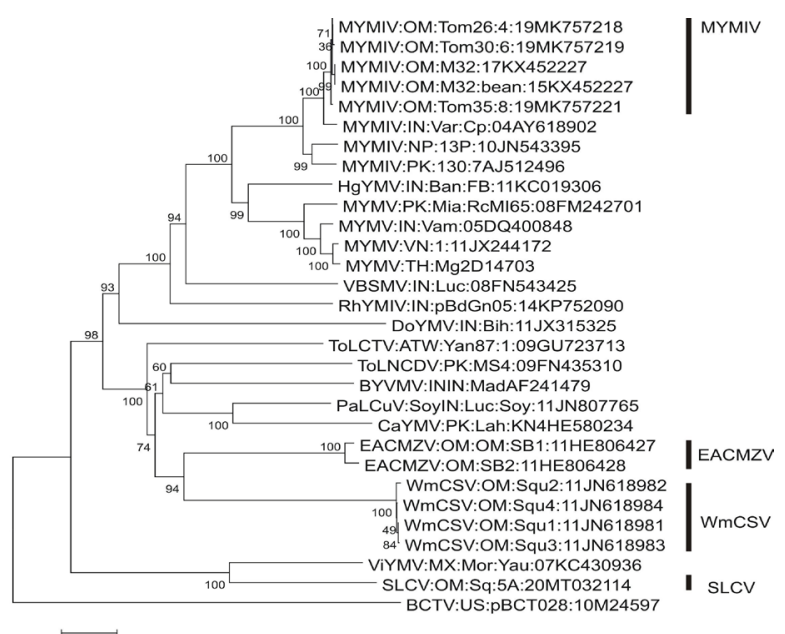

$\stackrel{0.050}{10}$

Figure 3. Neighbour-joining phylogenetic trees with 1000 bootstrap iterations and pairwise identity matching with aligned full-length genome sequences of selected begomoviruses with the GenBank accessions, representing different species of monopartite begomoviruses (a) and betasatellites (b).

\section{Tobacco (Nicotiana tabacum)}

Tobacco is grown in Oman in limited farms. In 2015, tobacco plants showing leaf curling (downward), yellowing, swelling of veins and stunting were noticed on tobacco plants in Suhar (Figure 4a). RCA was employed to augment the full genome of begomovirus and betasatellite. Full-length genome sequences of virus and betasatellite were determined and after analysis, it was found the variants of ChiLCV and ToLCB were linked with the leaf curl disease of tobacco (Shahid et al., 2019a). Moreover, pathogenicity of ChiLCV and ToLCB was verified by Agrobacterium-mediated inoculation into three $\mathrm{Ni}$ cotiana host plants (Shahid et al., 2019). Different begomoviruses have been identified from the tomato crop, however, ChiLCV is the only begomovirus infecting tobacco, along with the first detection of ToLCB in tobacco in Oman.

\section{Basil (Ocimum basilicum)}

Basil (Ocimum basilicum L.), family: Lamiaceae is a medicinal annually grown plant with purple-white flowers (Danechian et al., 2009). Basil is frequently utilized in cooking cosmetics a well as in traditional drugs (Klimánková et al., 2008). Due to its economic value basil is cultivated extensively and consumed as fresh, dried as a cooking spice and domestic use. Due to the rich source of antioxidant and active ingredient properties, basil is consumed for stomach aches as well as for skin diseases. During a field visit in 2014 in Al-Seeb, basil plants showing yellowing, curling and leaf crinkling symptoms were observed and collected. After the application of molecular tools, it was verified that the induction of symptoms in basil plants were due to the mixed infection by three monopartite begomoviruses TYLCV-OM, ToLCABV, and ChiLCV. Pairwise sequence analysis of complete ge-
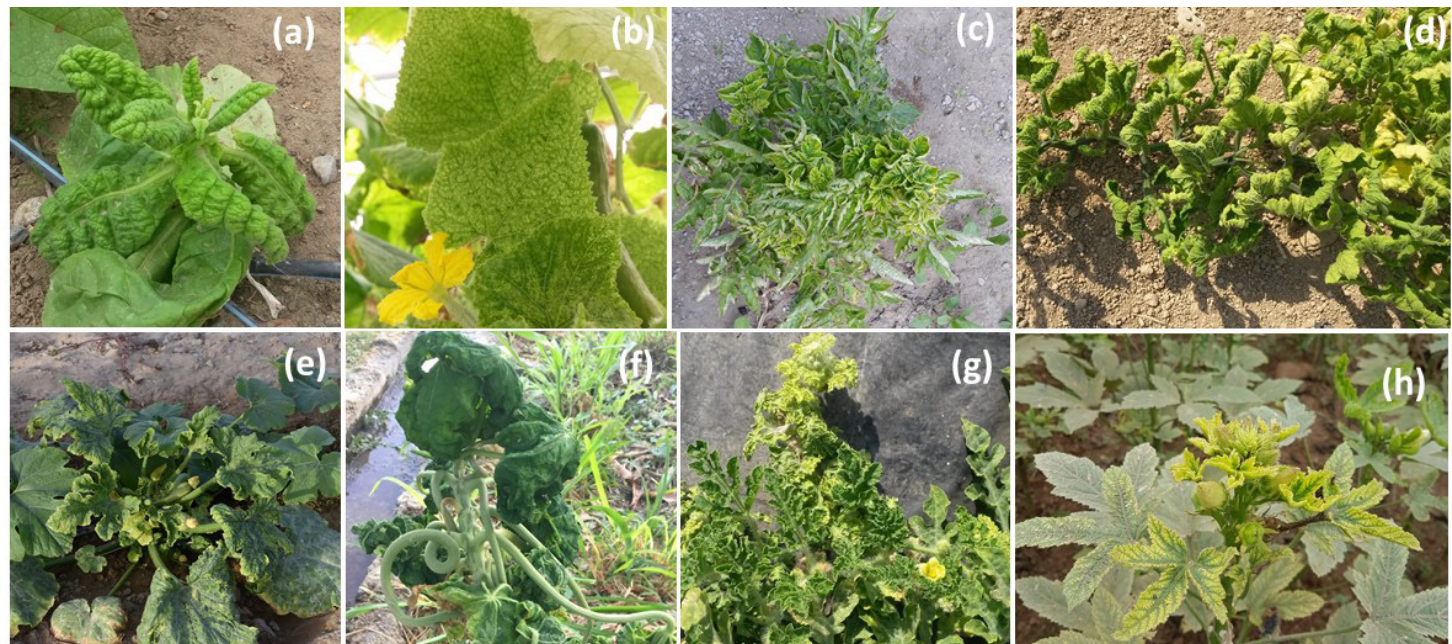

Figure 4. Different plant species infected by diverse begomoviruses and associated DNA satellites; tobacco (a), cucumber (b), tomato (c), Pumpkin (d), squash (e), papaya (f), watermelon (g), okra (h). 
nome sequences of TYLCV-OM, ToLCABV and ChiLCV showed 98\%, 99\% and 100\% nt identity, respectively, with the previously identified begomovirus strains in Oman. It was further confirmed that these viruses also harbour ToLCB, which exhibited 95\% nt identity with an isolate of ToLCB (Ammara et al., 2015) (Table 1).

\section{Weed}

A weed (Senna italica Mill) showing yellowing and stunting symptoms suspected to begomovirus infection with a moderate density of whiteflies was observed near an infected tomato field in Khasab, Musandam, Oman.
Molecular analysis and phylogenetic analysis using Species Demarcation Tool (SDT) confirmed the association of ChiLCV with ToLCB with $S$. italica plants (Salma et al., 2020 unpublished) (Figure 2A). S. italica is the first weed host in Oman co-infected with ChiLCV and ToLCB (Table 1).

\section{Mint}

Mint belongs to genus Mentha (Family: Lamiaceae). It is a valuable herb that has been grown and used for food as well as for medicinal purposes since centuries. During a survey in 2016 in Salalah, Oman, begomovi-

Table 1. List of all monopartite and bipartite begomoviruses and DNA satellites infecting different crops in Oman.

\begin{tabular}{|c|c|c|c|c|c|c|c|c|c|}
\hline Disease & $\begin{array}{c}\text { Virus(es) } \\
\text { identified }\end{array}$ & $\begin{array}{c}\text { Suggested } \\
\text { origin }\end{array}$ & Acronym & $\begin{array}{c}\text { Symptoms } \\
\text { produced }\end{array}$ & Host & $\begin{array}{c}\text { Detection } \\
\text { method }\end{array}$ & $\begin{array}{l}\text { Strain in } \\
\text { Oman }\end{array}$ & $\begin{array}{l}\text { Association } \\
\text { of satellite(s) }\end{array}$ & References(s) \\
\hline \multicolumn{10}{|c|}{ Monopartite begomoviruses } \\
\hline $\begin{array}{l}\text { Tomato } \\
\text { leaf curl } \\
\text { disease }\end{array}$ & $\begin{array}{l}\text { Tomato } \\
\text { yellow leaf } \\
\text { curl virus }\end{array}$ & $\begin{array}{l}\text { Middle } \\
\text { East and/ } \\
\text { or Medi- } \\
\text { terranean }\end{array}$ & TYLCV & Y, LC, S & $\begin{array}{l}\text { To- } \\
\text { mato, } \\
\text { Basil, } \\
\text { Radish }\end{array}$ & PCR/RCA & $\begin{array}{l}\text { TYL- } \\
\text { CV-OM }\end{array}$ & ToLCB & $\begin{array}{l}\text { Khan et al. } \\
(2008) \\
\text { Aummar et } \\
\text { al. (2016) } \\
\text { Al-Shihi et al. } \\
\text { (2018) }\end{array}$ \\
\hline $\begin{array}{l}\text { Bean } \\
\text { yellow } \\
\text { mosaic } \\
\text { disease }\end{array}$ & $\begin{array}{l}\text { Tomato } \\
\text { yellow leaf } \\
\text { curl virus }\end{array}$ & $\begin{array}{l}\text { Middle } \\
\text { East and/ } \\
\text { or Medi- } \\
\text { terranean } \\
\text { and } \\
\text { Indian } \\
\text { subconti- } \\
\text { nent }\end{array}$ & TYLCV & $\mathrm{YM}, \mathrm{LC}, \mathrm{Cr}$ & $\begin{array}{l}\text { Com- } \\
\text { mon } \\
\text { beans }\end{array}$ & RCA & $\begin{array}{l}\text { TYL- } \\
\text { CV-IR }\end{array}$ & ToLCB & $\begin{array}{l}\text { Shahid et al. } \\
(2018)\end{array}$ \\
\hline $\begin{array}{l}\text { Leaf } \\
\text { curl } \\
\text { disease }\end{array}$ & $\begin{array}{l}\text { Chili leaf } \\
\text { curl virus }\end{array}$ & $\begin{array}{l}\text { Indian } \\
\text { subconti- } \\
\text { nent }\end{array}$ & ChiLCV & $\mathrm{Y}, \mathrm{LC}, \mathrm{S}$ & $\begin{array}{l}\text { To- } \\
\text { mato, } \\
\text { Pepper, } \\
\text { Water- } \\
\text { melon, } \\
\text { Basil, } \\
\text { Radish, } \\
\text { Mint, } \\
\text { To- } \\
\text { bacco, } \\
\text { Urtica } \\
\text { incisa }\end{array}$ & PCR/RCA & $\begin{array}{l}\text { ChiL- } \\
\text { CV-OM }\end{array}$ & ToLCB & $\begin{array}{l}\text { Khan et al. } \\
\text { (2013a) } \\
\text { Shahid et al. } \\
\text { (2017a, 2017b, } \\
\text { 2019a, 2019d) } \\
\text { Al-Shihi et al. } \\
\text { (2018) }\end{array}$ \\
\hline $\begin{array}{l}\text { Tomato } \\
\text { leaf curl } \\
\text { disease }\end{array}$ & $\begin{array}{l}\text { Cotton } \\
\text { leaf curl } \\
\text { Gezira } \\
\text { virus }\end{array}$ & $\begin{array}{l}\text { North } \\
\text { Africa }\end{array}$ & CLCuGV & $\mathrm{SC}, \mathrm{VT}, \mathrm{VD}$ & $\begin{array}{l}\text { Pa- } \\
\text { paya, } \\
\text { Toma- } \\
\text { to }\end{array}$ & RCA & CLCuGV & ToLCB & $\begin{array}{l}\text { Khan et al. } \\
(2012 \mathrm{a})\end{array}$ \\
\hline $\begin{array}{l}\text { Okra } \\
\text { leaf curl } \\
\text { disease }\end{array}$ & $\begin{array}{l}\text { Okra leaf } \\
\text { curl virus }\end{array}$ & $\begin{array}{l}\text { North } \\
\text { Africa }\end{array}$ & OLCV & $\begin{array}{l}\text { VC, Y, RLA, } \\
\text { RFZ }\end{array}$ & Okra & PCR/RCA & $\begin{array}{l}\mathrm{OL}- \\
\mathrm{CV}-\mathrm{OM}\end{array}$ & $\begin{array}{l}\text { OLCB and } \\
\text { OLCA }\end{array}$ & $\begin{array}{l}\text { Khan et al. } \\
(2013 \mathrm{~b})\end{array}$ \\
\hline $\begin{array}{l}\text { Tomato } \\
\text { leaf curl } \\
\text { disease }\end{array}$ & $\begin{array}{l}\text { Tomato } \\
\text { leaf curl } \\
\text { Sudan } \\
\text { virus }\end{array}$ & $\begin{array}{l}\text { North } \\
\text { Africa }\end{array}$ & $\begin{array}{l}\text { ToLCS- } \\
\text { DV }\end{array}$ & VC, S, Y & $\begin{array}{l}\text { Toma- } \\
\text { to }\end{array}$ & PCR/RCA & $\begin{array}{l}\text { ToLCS- } \\
\text { DV-OM }\end{array}$ & ToLCB & $\begin{array}{l}\text { Khan et al. } \\
(2014 a)\end{array}$ \\
\hline $\begin{array}{l}\text { Tomato } \\
\text { leaf curl } \\
\text { disease }\end{array}$ & $\begin{array}{l}\text { Tomato } \\
\text { leaf curl } \\
\text { Al-Batinah } \\
\text { virus }\end{array}$ & $\begin{array}{l}\text { Middle } \\
\text { East and/ } \\
\text { or Indian } \\
\text { subconti- } \\
\text { nent }\end{array}$ & $\begin{array}{l}\text { ToL- } \\
\text { CABV }\end{array}$ & $\mathrm{VC}, \mathrm{S}, \mathrm{Y}$ & $\begin{array}{l}\text { To- } \\
\text { mato, } \\
\text { Basil }\end{array}$ & RCA & ToLCABV & ToLCB & $\begin{array}{l}\text { Khan et al. } \\
\text { (2013b) } \\
\text { Aummar et al. } \\
(2016)\end{array}$ \\
\hline $\begin{array}{l}\text { Tomato } \\
\text { leaf curl } \\
\text { disease }\end{array}$ & $\begin{array}{l}\text { Tomato } \\
\text { leaf curl } \\
\text { Barka } \\
\text { virus }\end{array}$ & $\begin{array}{l}\text { Middle } \\
\text { East and/ } \\
\text { or Indian } \\
\text { subconti- } \\
\text { nent }\end{array}$ & ToLCBrV & VC, S, Y & $\begin{array}{l}\text { Toma- } \\
\text { to }\end{array}$ & RCA & ToLCBrV & ToLCB & $\begin{array}{l}\text { Khan et al. } \\
\text { (2013b) }\end{array}$ \\
\hline $\begin{array}{l}\text { Tomato } \\
\text { leaf curl } \\
\text { disease }\end{array}$ & $\begin{array}{l}\text { Tomato } \\
\text { leaf curl } \\
\text { Liwa virus }\end{array}$ & $\begin{array}{l}\text { Middle } \\
\text { East and/ } \\
\text { or Indian } \\
\text { subconti- } \\
\text { nent }\end{array}$ & $\begin{array}{l}\text { ToLCL- } \\
\mathrm{wV}\end{array}$ & $\mathrm{Y}, \mathrm{VC}, \mathrm{S}$ & $\begin{array}{l}\text { To- } \\
\text { mato, } \\
\text { Basil }\end{array}$ & PCR/RCA & ToLCLwV & $\begin{array}{l}\text { ToLCB and } \\
\text { AYVSGA }\end{array}$ & $\begin{array}{l}\text { Idris et al. } \\
(2011) \\
\text { Amara et al. } \\
(2016)\end{array}$ \\
\hline
\end{tabular}




\begin{tabular}{|c|c|c|c|c|c|c|c|c|c|}
\hline \multicolumn{10}{|c|}{ Bipartite begomoviruses } \\
\hline $\begin{array}{l}\text { Cassava } \\
\text { mosaic } \\
\text { disease }\end{array}$ & $\begin{array}{l}\text { East } \\
\text { African } \\
\text { cassava } \\
\text { mosaic } \\
\text { Zanzibar } \\
\text { virus }\end{array}$ & $\begin{array}{l}\text { East } \\
\text { Africa }\end{array}$ & $\begin{array}{l}\text { EAC- } \\
\text { MZV }\end{array}$ & YM & Cassava & RCA & EACMZV & ToLCB & $\begin{array}{l}\text { Khan et al. } \\
\text { (2013a) }\end{array}$ \\
\hline $\begin{array}{l}\text { Mung- } \\
\text { bean } \\
\text { yellow } \\
\text { mosaic } \\
\text { disease }\end{array}$ & $\begin{array}{l}\text { Mungbean } \\
\text { yellow mo- } \\
\text { saic India } \\
\text { virus }\end{array}$ & $\begin{array}{l}\text { Indian } \\
\text { Subconti- } \\
\text { nent }\end{array}$ & MYMIV & Y, LC, S, YM & $\begin{array}{l}\text { Tomato, } \\
\text { Bean }\end{array}$ & $\begin{array}{l}\mathrm{PCR} / \mathrm{RCA} / \\
\mathrm{NGS}\end{array}$ & MYMIV & ToLCB & $\begin{array}{l}\text { Shahid et } \\
\text { al. (2019c, } \\
\text { 2019d) }\end{array}$ \\
\hline $\begin{array}{l}\text { Water- } \\
\text { melon } \\
\text { leaf curl } \\
\text { disease }\end{array}$ & $\begin{array}{l}\text { Water- } \\
\text { melon } \\
\text { chlorotic } \\
\text { stunt virus }\end{array}$ & $\begin{array}{l}\text { Middle } \\
\text { East and/ } \\
\text { or Africa }\end{array}$ & WmCSV & LC, $C, S$ & $\begin{array}{l}\text { Squash, } \\
\text { cucum- } \\
\text { ber }\end{array}$ & RCA/PCR & WmCSV & ToLCB & $\begin{array}{l}\text { Khan et al. } \\
\text { (2012b) } \\
\text { Shahid et al. } \\
(2019 c)\end{array}$ \\
\hline $\begin{array}{l}\text { Squash } \\
\text { leaf curl } \\
\text { disease }\end{array}$ & $\begin{array}{l}\text { Squash } \\
\text { leaf curl } \\
\text { virus }\end{array}$ & $\begin{array}{l}\text { Middle } \\
\text { East and/ } \\
\text { or Medi- } \\
\text { terranean }\end{array}$ & SLCV & SC, Y, S & Squash & RCA & SLCV & ToLCB & $\begin{array}{l}\text { Shahid et al. } \\
(2020)\end{array}$ \\
\hline
\end{tabular}

\begin{tabular}{|c|c|c|c|c|c|c|c|c|}
\hline \multicolumn{9}{|c|}{ DNA satellites } \\
\hline $\begin{array}{l}\text { Tomato } \\
\text { leaf curl } \\
\text { disease }\end{array}$ & $\begin{array}{l}\text { Tomato } \\
\text { leaf curl } \\
\text { betasatel- } \\
\text { lite }\end{array}$ & $\begin{array}{l}\text { Middle } \\
\text { East }\end{array}$ & ToLCB & VC, S, Y & Tomato & $\begin{array}{l}\text { PCR/RCA/ } \\
\text { NGS }\end{array}$ & ToLCB & $\begin{array}{l}\text { Shahid et al. } \\
\text { (2019) }\end{array}$ \\
\hline $\begin{array}{l}\text { Okra } \\
\text { leaf curl } \\
\text { disease }\end{array}$ & $\begin{array}{l}\text { Okra leaf } \\
\text { curl Oman }\end{array}$ & $\begin{array}{l}\text { Middle } \\
\text { East and/ } \\
\text { or Indian } \\
\text { subconti- } \\
\text { nent }\end{array}$ & OLCB & $\begin{array}{l}\text { VC, Y, RLA, } \\
\text { RFZ }\end{array}$ & Okra & PCR & OLCOMB & $\begin{array}{l}\text { Sohail et al. } \\
\text { (2014) }\end{array}$ \\
\hline $\begin{array}{l}\text { Tomato } \\
\text { leaf curl } \\
\text { disease }\end{array}$ & $\begin{array}{l}\text { Ageratum } \\
\text { yellow vein } \\
\text { Singapore } \\
\text { alphasat- } \\
\text { ellite }\end{array}$ & $\begin{array}{l}\text { South } \\
\text { East Asia } \\
\text { and/or } \\
\text { Indian } \\
\text { subconti- } \\
\text { nent }\end{array}$ & AYVSGA & $\mathrm{Y}, \mathrm{VC}, \mathrm{S}$ & Tomato & RCA & AYVSGA & $\begin{array}{l}\text { Idris et al. } \\
\text { (2011) }\end{array}$ \\
\hline $\begin{array}{l}\text { Okra } \\
\text { leaf curl } \\
\text { disease }\end{array}$ & $\begin{array}{l}\text { Okra leaf } \\
\text { curl Oman } \\
\text { alphasat- } \\
\text { ellite }\end{array}$ & $\begin{array}{l}\text { Middle } \\
\text { East }\end{array}$ & OLCA & $\begin{array}{l}\text { VC, Y, RLA, } \\
\text { RFZ }\end{array}$ & Okra & RCA & $\begin{array}{l}\text { OLCO- } \\
\text { MA }\end{array}$ & $\begin{array}{l}\text { Sohail et al. } \\
(2014)\end{array}$ \\
\hline
\end{tabular}

rus-like symptoms (leaf yellowing and stunting growth) of mint plants were seen. Young symptomatic leaves of mint plants were collected for begomovirus detection. The complete genome sequences of begomovirus analysis by using NCBI-BLAST tool http://blast.ncbi.nlm.nih. gov/Blast.cgi) verified the yellow and stunting symptoms of mint were due to the infection by a ChiLCV strain, which is different from the one reported earlier from tomato and pepper.

The SDT evaluation of ChiLCV sequences with available begomovirus sequences showed mint begomovirus to have high levels of nucleotide sequence similarity to isolates of the "Oman" strain of ChiLCV-OM, showing maximum nt identity 94.9\% (Muhire et al., 2014) (Figure 2A). This conclusion was further supported by phylogenetic analysis, which proved that mint begomovirus to be segregated along with ChiLCV isolates and is divergent from other ChiLCV strains (Table 1). The ChiLCV was also associated with betasatellite infection in Mentha (Shahid et al., 2019c). The SDT analysis showed 98.2\% nt identity with ToLCB isolate (KX452232) recently reported from Phaseolus vulgaris (Shahid et al., 2017a). In a phylogenetic study, ToLCB grouped with earlier ToL$\mathrm{CB}$ isolates identified from Arabian Peninsula, which are distinctive from South Asia isolates.

\section{Factors affecting Begomovirus Distribution and Spread in Oman}

Whitefly vector plays a crucial part in the transmission of begomoviruses. In Oman only $B$ tabaci MEAMI is reported, which can travel to limited distances, yet possibly, it contributes actively to the distribution of diverse virus species. However, we cannot ignore agriculture trade activities among countries either through land, sea, or air as they may help disseminate the insect vector into different geographical locations. Another 
contributing factor is human movement, which also contributes to the spread of viruses. However, there are other reasons including virus mutation, recombination, polyphagous nature of the vector, rigorous agricultural procedures like growing of single crop or cultivation of a single plant cultivar, cultivation of susceptible cultivars and the world-wide transport of agricultural goods are thought to increase the emergence and proliferation of viruses. Hence, begomoviruses form a major risk to the worldwide food security. Policies must be designed to prevent continuous crop failures due to plant infecting viruses and avoid the transport and spread of these lethal pathogens into new places (where environmental factors are suitable to enhance the population density of the whitefly vector). Environmental factors play a key role in plant-virus interaction, where an optimal temperature can influence disease development, disease severity and/ or incidence. For instance, Papaya ringspot virus can multiply, infect, and transmit virus to papaya plants ideally between $26^{\circ} \mathrm{C}$ to $31^{\circ} \mathrm{C}$ (Mangrauthia et al., 2009). In cassava plants, Cassava mosaic virus (genus; begomoviruses family; Geminiviradae), enhanced symptoms and viral titres at $25{ }^{\circ} \mathrm{C}$, compared to $30{ }^{\circ} \mathrm{C}$ (Chellappan et al., 2005). Banana bunchy top virus, which is vectored by an aphid (Pentalonia nigronervosa), can actively develop and has lowest mortality at $25^{\circ} \mathrm{C}$ (Robson et al., 2007). Heat and drought have also an impact on the severity of viral diseases. Such as, in Arabidopsis heat, drought and turnip mosaic virus synergistically reduced the plant growth than the individual factor (Prasch et al., 2013).

\section{Conclusion and Prospects}

Despite the existence of diverse viruses and DNA satellites that have their origin out of Oman, there is no indication that these begomoviruses are spreading out from Oman. However, to restrict the movement of these pathogens, trade products could be regulated by improved phytosanitary measures. For instance, for different import commodities arriving at Sohar port, hard quarantine should be applied to kill the insect vectors, particularly in containers importing wood products. Similar precautionary measures should be applied for the imports through airports and road border (UAE, Saudi Arabia and Yemen). The propagative plant materials/ nursery stocks should be given special attention when inspecting diseases or insect pests. For example, Oman has introduced approximately one million tons of propagative plant material in 2012, which could have harboured vectors and diseases, including begomoviruses. One latest example is the introduction of begomovirus disease of cotton in China, which is believed to be due to the negligence of quarantine material in import of ornamental plants (Sattar et al., 2013). Additionally, we cannot ignore the emergence of new and recombinant begomoviruses and DNA satellite strains that could evolve in one place and spread out through the same trade routes, which are believed to bring the pathogens initially into the country. Hence, to avoid further trade of Geminiviruses, Oman requires to set-up a phytosanitary facility equipped with the latest virus detection and discovery technologies.

\section{Acknowledgement}

The funds were provided by Sultan Qaboos University to M.S. Shahid, under internal and research fund grants.

\section{References}

Akhtar S, Khan AJ, Singh AS, Briddon RW. (2014). Identification of a disease complex involving a novel monopartite begomovirus with beta- and alphasatellites associated with okra leaf curl disease in Oman. Archives of Virology 159: 1199-1205.

Al-Shihi AAM, Khan AJ, Akhtar S, Lima ATM, Zerbini FM, Briddon RW. (2014). Occurrence of new recombinant begomovirus species infecting tomato in the Al Batinah region of Oman. Plant Pathology 63: 1177-1184.

Al-Shihi AA, Al-Sadi, AM, Deadman M, Briddon RW, Shahid M.S. (2018a). Identification of a distinct strain of Cotton leaf curl Gezira virus infecting tomato in Oman. Journal of Phytopathology 166(3): 199-205.

Al-Shihi AA, Hanson P, Al-Sadi AM, Al-Yahyai A, Briddon RW, Deadman M, Shahid MS. (2018b). Evaluation of tomato inbred lines for resistance to the tomato yellow leaf curl disease complex in Oman. Crop Protection 110: 91-98.

Ammara UE, Al-Ansari M, Al-Shihi A, Amin I, Mansoor S, Al-Maskari AY, Al-Sadi AM. (2015). Association of three begomoviruses and a betasatellite with leaf curl disease of basil in Oman. Canadian Journal of Plant Pathology 37(4): 506-513.

Briddon RW, Bull SE, Mansoor S, Amin I, Markham PG. (2002). Universal primers for the PCR-mediated amplification of DNA $\beta$; a molecule associated with some monopartite begomoviruses. Molecular Biotechnology 20: 315-318.

Briddon RW, Bull SE, Amin I, Idris AM, Mansoor S, Bedford ID, Dhawan P, Rishi N, Siwatch SS, Abdel-Salam AM. (2003). Diversity of DNA $\beta$ : a satellite molecule associated with some monopartite begomoviruses. Virology 312: 106-121.

Chellappan P, Vanitharani R, Ogbe F, Fauquet CM. (2005). Effect of temperature on geminivirus-induced RNA silencing in plants. Plant Physiology 138(4): 1828-1841.

Czosnek H, Hariton-Shalev A, Sobol I, Gorovits R, Ghanim M. The incredible journey of begomoviruses in their whitefly vector. Viruses. 2017; 9(10):273.

Danechian A, Gurbuz B, Cosge B, Ipek A. (2009). Chem- 
ical components of essential oils from basil (Ocimum basilicum L.) grown at different nitrogen levels. International Journal of Engineering, Science and Technology 3: 9-13.

Dhanraj KS, Seth ML. (1968). Enation in Capsicum annum L (Chilli) caused by a new strain of leaf curl virus. Indian Journal of Horticulture 25: 70-71.

Idris AM, Shahid MS, Briddon RW, Khan AJ, Zhu J-K, Brown JK. (2011). An unusual alphasatellite associated with monopartite begomoviruses attenuates symptoms and reduces betasatellite accumulation. Journal of General Virology 92: 706-717.

Idris A, Al-Saleh M, Amer M, Abdalla O, Brown J. (2014). Introduction of Cotton leaf curl Gezira virus into the United Arab Emirates. Plant Disease 98: 1593-1593.

Khan A, Idris A, Al-Saady N, Al-Mahruki M, Al-Subhi A, Brown J. (2008). A divergent isolate of Tomato yellow leaf curl virus from Oman with an associated DNA $\beta$ satellite: an evolutionary link between Asian and the Middle Eastern virus-satellite complexes. Virus Genes 36: 169-176.

Khan AJ, Akhtar S, Al-Matrushi AM, A-Shihi AA, Al-Hinai FM, Briddon R. (2012a). Identification of Cotton leaf curl Gezira virus in papaya in Oman. Plant Disease 96(11): 1704.

Khan AJ, Akhtar S, Briddon RW, Ammara U, Al-Matrushi AM, Mansoor S. (2012b). Complete nucleotide sequence of Watermelon chlorotic stunt virus originating from Oman. Viruses 4: 1169-1181.

Khan AJ, Akhtar S, Al-Matrushi AM, Fauquet CM, Briddon RW. (2013a). Introduction of East African cassava mosaic Zanzibar virus to Oman harks back to "Zanzibar, the capital of Oman". Virus Genes 46: 195-198.

Khan AJ, Akhtar S, Al-Zaidi AM, Singh AK, Briddon RW. (2013b). Genetic diversity and distribution of a distinct strain of Chili leaf curl virus and associated betasatellite infecting tomato and pepper in Oman. Virus Research 177: 87-97.

Khan AJ, Akhtar S, Singh AK, Briddon RW. (2013c). A distinct strain of Tomato leaf curl Sudan virus causes tomato leaf curl disease in Oman. Plant Disease 97: 1396-1402.

Khan AJ, Akhtar S, Singh AK, Al-Shehi AA, Al-Matrushi AM, Ammara U, Briddon RW. (2014a). Recent evolution of a novel begomovirus causing tomato leaf curl disease in the Al-Batinah region of Oman. Archives of Virology 159: 445-455.

Khan AJ, Mansoor M, Briddon RW. (2014b). Oman: a case for a sink of begomoviruses of geographically diverse origins. Trends in Plant Sciences 19: 67-70.

Klimánková E, Holadová K, Hajšlová J, Čajka T, Poustka J, Koudela M. (2008). Aroma profiles of five basil (Ocimum basilicum L.) cultivars grown under con- ventional and organic conditions. Food Chemestry 107: 464-472.

Mangrauthia SK, Singh Shakya VP, Jain RK, Praveen S. (2009). Ambient temperature perception in papaya for papaya ringspot virus interaction. Virus Genes 38(3): 429-434.

Muhire BM, Varsani A, Martin DP. (2014). SDT: A virus classification tool based on pairwise sequence alignment and identity calculation. PLoS ONE 9: 1-8.

Prasch CM, (2013). Sonnewald U. Simultaneous application of heat, drought, and virus to Arabidopsis plants reveals significant shifts in signaling networks. Plant Physiology 162: 1849-1866.

Robson JD, Wright MG, Almeida RPP. (2007). Biology of Pentalonia nigronervosa (Hemiptera, Aphididae) on banana using different rearing methods. Environmental Entomology 36(1): 46-52.

Rosario K, Marr C, Varsani A. (2015). Begomovirus-Associated Satellite DNA Diversity Captured Through Vector-Enabled Metagenomic (VEM) Surveys Using Whiteflies (Aleyrodidae). Viruses 8: 1-16 (Article 36).

Sattar MN, Kvarnheden A, Saeed M, Briddon RW. (2013). Cotton leaf curl disease-an emerging threat to cotton production worldwide. Journal of General Virology 94: 695-710.

Saunders K, Stanley J. (1999). A nanovirus-like component associated with yellow vein disease of Ageratum conyzoides: evidence for interfamilial recombination between plant DNA viruses. Virology 264: 142-152.

Saunders K, Norman A, Gucciardo S, Stanley J. (2004). The DNA $\beta$ satellite component associated with ageratum yellow vein disease encodes an essential pathogenicity protein ( $\beta C 1)$. Virology 324: 37-47.

Saunders K, Briddon RW, Stanley J. (2008). Replication promiscuity of DNA- $\beta$ satellites associated with monopartite begomoviruses; deletion mutagenesis of the Ageratum yellow vein virus DNA- $\beta$ satellite localises sequences involved in replication. Journal of General Virology 89: 3165-3172.

Al-Mabsili S, Al-Wahibi AK, Al-Sadi MA, Shahid MS. (2020). Association of a monopartite begomovirus and associated betasatellite with yellow vein disease of a weed host, Senna italica Mill in Oman (unpublished VirusDisease).

Shafiq M, Sattar MN, Shahid MS, Al-Sadi AM, Briddon RW. (2020). Interaction of watermelon chlorotic stunt virus with satellites. Australasian Plant Pathology 3: $1-2$.

Shahid MS, Briddon RW, Al-Sadi MA. (2017a). Identification of Mungbean yellow mosaic India virus associated with tomato leaf curl betasatellite infecting Phaseolus vulgaris in Oman. Journal of Phytopathology 165: 204-211. 
Shahid MS, Al-Sadi AM, Briddon RW. (2017b). First report of Chilli leaf curl virus and tomato leaf curl betasatellite infecting watermelon (Citrullus lanatus) in Oman. Plant Disease 101(6): 1063.

Shahid MS, Al-Mahmooli IH, Al-Sadi MA, Briddon RW. (2018). Identification of Mungbean yellow mosaic Indian virus infecting cucumber in Oman. Plant Disease 102: 465-465.

Shahid, M.S., Shafiq, M., Raza, A., Al-Sadi, M. A. and Briddon, R. W. (2019a). Molecular and biological characterization of Chilli leaf curl virus and associated Tomato leaf curl betasatellite infecting tobacco in Oman. Virol Journal 16: 1-9 (Article 131).

Shahid MS, Shafiq M, Ilyas M, Raza A, Al-Sadrani, MN, Al-Sadi MA, Briddon RW. (2019b). Frequent occurrence of Mungbean yellow mosaic India virus in tomato leaf curl disease affected tomato in Oman. Scientific Report 9: 1-14 (Article 16634).

Shahid MS, Raza A, Shafiq M, Al-Sadi MA, Briddon RW. (2019c). Identification of chili leaf curl virus associated with tomato leaf curl betasatellite infecting Mentha in Oman. Canadian Journal of Plant Pathology 41(2): 291-295.

Shahid MS, Raza A, Shafiq M, Al-Sadi AM, Briddon RW. (2019d). Infection of Urtica incisa with chili leaf curl virus and tomato leaf curl betasatellite in Oman. Journal of Plant Pathology 101: 395-395.
Shahid MS. (2020a). Tomato yellow leaf curl virus interaction with betasatellites-a global threat to tomato production. Plant Pathology 69: 1191-1192.

Shahid MS. (2020b). Molecular and biological characterization of Chilli leaf curl virus and associated betasatellite infecting Cucurbita maxima in Oman. Virus Disease 31: 378-382.

Shahid MS, Al-Sulaimani H, Al-Sadi AM. Squash leaf curl virus: (2020c). A New World bipartite begomovirus threatening squash production in Oman. Plant Disease 104(9) (in press).

Tsai WS, Shih SL, Rauf A, Safitri R, Hidayati N, Huyen BTT, Kenyon L. (2013). Genetic diversity of legume yellow mosaic begomoviruses in Indonesia and Vietnam. Annual Appllied Biology 163: 367-377.

Zerbini FM, Briddon RW, Idris A, Martin DP, Moriones E, Navas-Castillo J, Rivera-Bustamante R, Varsani A, Consortium IR. (2017). ICTV Virus Taxonomy Profile: Geminiviridae. Journal of General Virology 98: 131-133.

Zhou X. (2013). Advances in understanding begomovirus satellites. Annual Review of Phytopathology 51: 357-381. 